\title{
Quantification and qualification of exhaust gases in agricultural diesel engine operating with biodiesel mixtures
}

\author{
Flávio C. da Silva ${ }^{1}$, Felipe N. Aranha ${ }^{1}$, Gerd B. Angelkorte², Juan F. H. Guardiola ${ }^{1}$, \\ Luciana P. Teixeira ${ }^{3} \&$ Ricardo C. de B. Correia ${ }^{1}$
}
${ }^{1}$ Universidade Federal Fluminense/ Departamento de Engenharia Agrícola e Meio Ambiente/Programa de Pós-Graduação em Engenharia de Biossistemas. Niterói, RJ, Brasil. E-mail: flaviocastro@id.uff.br (Corresponding author) - ORCID: 0000-0003-1366-9806; felipearanha@id.uff.br - ORCID: 0000-0002- 1459-9187; juanfer_hegu@hotmail.com - ORCID: 0000-0002-4004-4783; ricardocromack@gmail.com - Orcid: 0000-0003-3242-7087
${ }^{2}$ Universidade Federal do Rio de Janeiro/Instituto Alberto Luiz Coimbra de Pós-Graduação e Pesquisa de Engenharia/Programa de Planejamento Energético. Rio de janeiro, RJ, Brasil. E-mail: angelkorte@ppe.ufrj.br - ORCID: 000-0003-0385-4565
${ }^{3}$ Universidade Santa Úrsula. Rio de Janeiro, RJ, Brasil. E-mail: lucianapteixeira@yahoo.com.br - ORCID: 0000-0001-7355-6200

\begin{abstract}
Diesel cycle engines are widely used in agricultural machinery. Biodiesel offers the possibility of partial or total replacement of mineral diesel, thus reducing the dependence of agriculture on this nonrenewable resource and decreasing pollutant emissions. The objective of this study was to evaluate the emissions of $\mathrm{CO}, \mathrm{NO}_{\mathrm{x}}, \mathrm{SO}_{2}, \mathrm{CO}_{2}$, and $\mathrm{O}_{2}$ from various biodiesel mixtures $(\mathrm{B} 0=0 \%, \mathrm{~B} 7=7 \%, \mathrm{~B} 10=10 \%$, $\mathrm{B} 20=20 \%, \mathrm{~B} 30=30 \%$ and $\mathrm{B} 100=100 \%)$ in a single-cylinder tractor engine at 1000,1600 and $2400 \mathrm{rpm}$. The exhaust gases were identified using a gas probe meter. Fuels with a higher percentage of biodiesel have the lowest $\mathrm{SO}_{2}$ emissions, with the $\mathrm{B} 30$ mixture releasing 65.78, 52.47 and 32.25 parts per million at 1000, 1600 and $2000 \mathrm{rpm}$, respectively. Nitrous oxides and carbon dioxide emissions decreases with higher engine rotation speed. Higher percentages of biodiesel result in less polluting fuels.
\end{abstract}

Key words: gas emissions, agricultural tractor, biofuels

\section{Quantificação e qualificação dos gases de escape em motor agrícola diesel operando com misturas de biodiesel}

RESUMO: Motores de ciclo diesel são amplamente utilizados em máquinas agrícolas. O biodiesel oferece a possibilidade de substituição parcial ou total do diesel mineral, reduzindo assim a dependência da agricultura desse recurso não renovável e diminuindo as emissões de poluentes. O objetivo deste estudo foi avaliar as emissões de $\mathrm{CO}, \mathrm{NO}_{\mathrm{x}}, \mathrm{SO}_{2}, \mathrm{CO}_{2}$ e $\mathrm{O}_{2}$ de várias misturas de biodiesel $(\mathrm{B} 0=0 \%, \mathrm{~B} 7=7 \%, \mathrm{~B} 10=10 \%, \mathrm{~B} 20$ $=20 \%, \mathrm{~B} 30=30 \%$ e B100 = 100\%) em um motor agrícola monocilíndrico a 1000, 1600 e $2400 \mathrm{rpm}$. Os gases de escape foram identificados usando um medidor de gás. Os combustíveis com maior porcentagem de biodiesel têm as menores emissões de $\mathrm{SO}_{2}$, com a mistura $\mathrm{B} 30$ liberando 65,78, 52,47 e 32,25 partes por milhão a 1000, 1600 e $2000 \mathrm{rpm}$, respectivamente. As emissões de óxidos nitrosos e de dióxido de carbono diminuem com o aumento da velocidade de rotação do motor. Maiores porcentagens de biodiesel resultam em combustíveis menos poluentes.

Palavras-chave: emissões de gases, trator agrícola, biocombustíveis 


\section{INTRODUCTION}

Since the industrial revolution made the human increasingly dependent on fossil fuels, concentrations of greenhouse gases have risen to critical levels. It is estimated that $75 \%$ of these concentrations are the result of burning fuels (Reis et al., 2013).

The search for alternative fuels to supply and/or replace fossil fuels is ongoing. Biodiesels are a potential alternative, as they are renewable, biodegradable, non-toxic, offer reduced sulfur emissions, have superior lubrication, and can significantly reduce greenhouse gas emissions (Vichi \& Mansor, 2009).

As modernization and industrialization continue around the world, the demand for energy is ever-increasing. The burning of fossil fuels degrades the environment, especially from the emission of gases that are harmful to human health and to the atmosphere (Hasan \& Rahman, 2017).

Biodiesels are advantageous because they have a similar or higher cetane number than diesel. Additionally, they are nontoxic, biodegradable, good lubricants, and require little or no modification to the engine because their properties are similar to those of diesel (Islam et al., 2014). However, biodiesels have some disadvantages, such as their low volumetric energy, high kinematic viscosity, and high $\mathrm{NO}_{\mathrm{x}}$ emissions (Can et al., 2017).

This study attempts to identify and quantify the exhaust gases from a diesel engine operating at different rotation speeds and with different biodiesel mixtures.

\section{Material ANd Methods}

To obtain different fuel blends, biodiesels with a high degree of homogeneity were produced from soybean oil. Pure mineral diesel was acquired from Distribuidora de Produtos de Petróleo Ipiranga S/A.

The biodiesel production and mixture preparation were carried out at the Agricultural Machinery Laboratory (LABMAQ) in the Departamento de Engenharia Agrícola e Ambiental of the Universidade Federal Fluminense (UFF). The biodiesel was produced by transesterification via the methyl route in proportions of 1 mole of soybean oil to 6 moles of $99.7 \%$ p.a. methyl alcohol, in accordance with the procedure described by Tomasevic \& Siler-Marinkovic (2003).

The various mixtures produced are denoted as $\mathrm{B} 0=0 \%$, $\mathrm{B} 7=7 \%, \mathrm{~B} 10=10 \%, \mathrm{~B} 20=20 \%, \mathrm{~B} 30=30 \%$ and $\mathrm{B} 100=100 \%$. This nomenclature indicates the percentage of biodiesel in pure diesel (petrodiesel), i.e., $\mathrm{Bx}$, where $\mathrm{x}$ is the percentage. These mixtures were selected according to the market utilization criterion and government regulations. B7 was in force in Brazil until 2017, when the increase of biodiesel in the blend reached $8 \%$. The use of B10 was authorized in 2018. The B20 had its voluntary use authorized for captive fleets and road consumers; the $\mathrm{B} 30$ is used in rail transportation and industrial agricultural vehicles; finally, B100 is authorized for experimental use in accordance with the Agência Nacional do Petróleo, Gas Natural e Biocombustível (ANP) Resolution No. 30 (ANP, 2016a).

The physico-chemical characterization of the biodiesels was carried out at the Rheology Laboratory (LARE) of the Departamento de Engenharia Mecânica of the Universidade
Federal Fluminense (UFF). The characterization phase of the produced fuel aimed to verify its quality according to ANP specifications. The specific mass and kinematic viscosity of biodiesel were evaluated in accordance with Resolution No. 30 (ANP, 2016a), Resolution No. 45 (ANP, 2014) and Resolution No. 46 (ANP, 2016b). To define the temperature as a function of the specific mass, a pycnometer in a thermostatic bath was used to determine the specific mass of each biodiesel. After measuring the weight of the pycnometer with and without biodiesel, the specific mass of each biodiesel was calculated as:

$$
\rho=\frac{P p /(b-P p)}{V p} 1000
$$

where:

$\rho \quad$ - biodiesel specific mass, $\mathrm{kg} \mathrm{m}^{-3}$;

$\mathrm{Pp} / \mathrm{b}$ - weight of the pycnometer/biodiesel set, g;

Pp - pycnometer weight, g; and,

$\mathrm{Vp}$ - pycnometer volume, $\mathrm{mL}$.

The kinematic viscosity at $40{ }^{\circ} \mathrm{C}$ was determined by the capillary viscometer method with the aid of CannonFenske-type viscometers. These viscometers were calibrated by measuring the kinematic viscosity of distilled water at $40{ }^{\circ} \mathrm{C}$ and that of a thermostatic bath (N480, New Ethics) with a transparent thermostat (CT52, Schott). This allowed the biodiesel to be stabilized at $40{ }^{\circ} \mathrm{C}$ and the biodiesel flow to be visualized in the capillary viscometer.

The determination of the biodiesels kinematic viscosity was initiated by adjusting the thermostatic bath to $40{ }^{\circ} \mathrm{C}$ and placing a small amount of fluid, sufficient to fill $2 / 3$ of the lower bulb of the viscometer, in the thermostatic bath. After the biofuel had reached $40^{\circ} \mathrm{C}$, the time taken for it to traverse the two control marks of the viscometer was measured. This procedure was repeated five times for each fuel and the mean for each test was computed. After obtaining the mean time for each biodiesel to flow from the first mark to the second one, the kinematic viscosity was calculated as:

$$
\mathrm{v}=\mathrm{t} \mathrm{c}
$$

where:

$v \quad$ - biodiesel kinematic viscosity, $\mathrm{mm}^{2} \mathrm{~s}^{-1}$;

$\mathrm{t}$ - time for biodiesel to flow between the marks of the capillary viscometer, s; and,

c - capillary viscometer constant, $\mathrm{mm}^{2} \mathrm{~s}^{-2}$.

The experiments used a micro-tractor with a singlecylinder air-cooled engine of capacity $668 \mathrm{~cm}^{3}, 4.0 \mathrm{kgf} \mathrm{m}$ maximum torque at $2350 \mathrm{rpm}$ and $14.7 \mathrm{hp}(10.8 \mathrm{~kW})$ power at $2750 \mathrm{rpm}$ (NBR ISO 1585). Rotation speeds of 1000, 1600 and $2400 \mathrm{rpm}$ were investigated, as these characterize the rotations in the idling speed, operating rotation and maximum speed ranges, according to the manufacturer's information, operating on a stationary basis. The engine was supplied by an external tank, and the mixtures were tested in increasing order from B0 to B100. Between testing each fuel supply, the tank was completely cleaned by means of washing and 
drying, as well as replacing the feeding hose to avoid sample contamination.

The gas meter consisted of a TESTO ${ }^{\circledR}$ model $350 \mathrm{XL}$ gas analyzer with a gas probe coupled to the engine exhaust pipe. This analyzer is capable of verifying the amount of CO, NO, $\mathrm{NO}_{2}, \mathrm{SO}_{2}, \mathrm{CO}_{2}, \mathrm{O}_{2}$, and $\mathrm{H}_{2}$ gases released to the environment by combustion.

For each fuel, the tractor was running for $16 \mathrm{~min}$. Within this time, three data collections of 2 min each were performed, with 5-min intervals between them. Between tests with different fuels, the engine was allowed to cool to room temperature. The experiments used a completely randomized design with three repetitions for each fuel, whereby the fuel was fixed and the rotation speeds were varied for each test. The variables to be analyzed were programmed in the gas analyzer software, where 120 data points (one per second for $2 \mathrm{~min}$ ) were recorded for each gas. As there were three repetitions, the analyzer was configured for 360 emission data for each of the analyzed gases.

The SISVAR free software (Ferreira, 2014) was used to perform analyses of variance and Tukey tests at $\mathrm{p} \leq 0.05$.

\section{Results AND Discussion}

The kinematic viscosity values for the tested fuels ranged from $2.8513-4.0413 \mathrm{~mm}^{2} \mathrm{~s}^{-1}$ and the specific mass values ranged from $830.28-883.18 \mathrm{~kg} \mathrm{~m}^{-3}$ (Table 1). These are in accordance with ANP Resolution No. 45 (ANP, 2014), which states that biodiesels must have a kinematic viscosity of 3.0-6.0 $\mathrm{mm}^{2} \mathrm{~s}^{-1}$ at $40{ }^{\circ} \mathrm{C}$ and $991.0 \mathrm{~kg} \mathrm{~m}^{-3}$ maximum specific mass at $20^{\circ} \mathrm{C}$.

The American Society for Testing and Materials (ASTM) specifies kinematic viscosity values of $1.9-6.0 \mathrm{~mm}^{2} \mathrm{~s}^{-1}$, but does not suggest any values for the specific mass (Hasan \& Rahman, 2017). According to Öztürk (2015), EN 14214 of the European Committee for Standardization specifies that the kinematic viscosity of pure biodiesel should range from $3.5-5.0 \mathrm{~mm}^{2} \mathrm{~s}^{-1}$; and the specific mass must be $860-900 \mathrm{~kg} \mathrm{~m}^{-3}$. In this study, the pure biodiesel exhibited kinematic viscosity and specific mass values of $4.0413 \mathrm{~mm}^{2} \mathrm{~s}^{-1}$ and $883.18 \mathrm{~kg} \mathrm{~m}^{-3}$, respectively, which comply with the European standard. Peng (2015) studied the physico-chemical characterization of soybean oil-based biodiesel and reported a value of $4.45 \mathrm{~mm}^{2} \mathrm{~s}^{-1}$ for the kinematic viscosity.

Note that, for both the kinematic viscosity and the specific mass, the values increased with the percentage of biodiesel; however, the values were close to and within the acceptable values stated above.

Lahane \& Subramanian (2015) investigated the specific masses of mixtures from B5 to B100, and obtained results

Table 1. Characterization of fuel variables

\begin{tabular}{|ccc|}
\hline $\begin{array}{c}\text { Biodiesel } \\
\text { mixture }\end{array}$ & $\begin{array}{c}\text { Kinematic viscosity } \\
\left(\mathrm{mm}^{2} \mathrm{~s}^{-1}\right)\end{array}$ & $\begin{array}{c}\text { Specific mass } \\
\left(\mathrm{kg} \mathrm{m}^{-3}\right)\end{array}$ \\
\hline B0 & $2.8513 \mathrm{f}$ & $830.28 \mathrm{f}$ \\
B7 & $2.9377 \mathrm{e}$ & $834.02 \mathrm{e}$ \\
B10 & $2.9795 \mathrm{~d}$ & $835.59 \mathrm{~d}$ \\
B20 & $3.0886 \mathrm{C}$ & $840.89 \mathrm{C}$ \\
B30 & $3.1918 \mathrm{~b}$ & $846.22 \mathrm{~b}$ \\
B100 & $4.0413 \mathrm{a}$ & $883.18 \mathrm{a}$ \\
\hline
\end{tabular}

$\mathrm{B} 0=0 \%, \mathrm{~B} 7=7 \%, \mathrm{~B} 10=10 \%, \mathrm{~B} 20=20 \%$, B $30=30 \%$ and B100 $=100 \%$; Values followed by the same letter do not differ according to Tukey test at $\mathrm{p} \leq 0.05$ of $823.1-893.6 \mathrm{~kg} \mathrm{~m}^{-3}$. The same authors concluded that the specific mass increased with the biodiesel content in the diesel. The present study confirms these results.

According to Kumar \& Sharma (2016), CO is produced by incomplete combustion in the engine cylinder and partially oxidized carbon particles. In this study, the $\mathrm{CO}$ emissions at $1000 \mathrm{rpm}$ displayed a different behavior from those at 1600 and $2400 \mathrm{rpm}$, increasing with the level of biodiesel in the fuel (Table 2).

The $\mathrm{CO}$ emissions using $\mathrm{B} 0$ increase with the engine rotation speed, whereas those for fuels from B7 to B20 decrease when the engine is operating at $1600 \mathrm{rpm}$ and increase at 2400 rpm. Analyzing mixtures B30 and B100, it is clear that the lowest emissions occur at $1600 \mathrm{rpm}$ and the highest emissions occur at $1000 \mathrm{rpm}$. While for B100 and B30, the highest emissions occur at the lowest rotation speed, whereas for B0 and B7, the highest emissions occur at the highest rotation speed. These results corroborate the work of Nalgundwar et al. (2016), who claimed that high CO emissions in higher biodiesel mixtures can be justified by the high viscosity and poor air-fuel mixture.

According to Gharehghani et al. (2017), the combustion temperature and amount of available unburnt fuel control the rate of decomposition and oxidation of the fuel and, consequently, the $\mathrm{CO}$ formation rate. Accordingly, it can be stated that, at $1000 \mathrm{rpm}$, the combustion temperature was insufficient to produce a complete burn, thus releasing more $\mathrm{CO}$, when the biodiesel percentage increased or when there was a larger injection of these fuels, resulting in a poorer mixture.

Lahane \& Subramanian (2015) concluded that CO emissions decrease in biodiesel mixtures because of the high amount of oxygen. Cleaner and more complete combustion occurs with the help of oxygen by reducing $\mathrm{CO}$ emissions.

Perin et al. (2015) identified a 73.2\% decrease in CO emissions when utilizing B100 (pure biodiesel) compared with $\mathrm{B} 5$. The authors stated that biodiesel contains $10-12 \% \mathrm{O}_{2}$, depending on the raw material.

According to Ganjehkaviri et al. (2016), the rate of $\mathrm{NO}_{\mathrm{x}}$ formation in biodiesel combustion is a controversial issue. The authors believe that the viscosity increase is caused by an increase in the length of the biodiesel molecules which prevents the nitrogen molecules from reacting with oxygen molecules present in biodiesel. This results in a lower formation of $\mathrm{NO}_{\mathrm{x}}$. Moreover, this corroborates the results found in the present study.

The results indicate a slight reduction in $\mathrm{NO}_{\mathrm{x}}$ at $1000 \mathrm{rpm}$ when using the biodiesel mixtures compared with pure diesel

Table 2. Emissions of CO ( $\mathrm{ppm}$ ) for different fuels and rotation speeds

\begin{tabular}{lccc}
\hline \multirow{3}{*}{ Fuel } & \multicolumn{3}{c}{ Rotation (rpm) } \\
\cline { 2 - 4 } B0 & $\mathbf{1 0 0 0}$ & $\mathbf{1 6 0 0}$ & $\mathbf{2 4 0 0}$ \\
B7 & $270.19 \mathrm{Ec}$ & $300.68 \mathrm{Ab}$ & $347.06 \mathrm{Aa}$ \\
B10 & $282.76 \mathrm{Cb}$ & $268.13 \mathrm{Cc}$ & $319.08 \mathrm{Ba}$ \\
B20 & $269.10 \mathrm{~Eb}$ & $259.87 \mathrm{Dc}$ & $314.46 \mathrm{Ca}$ \\
B30 & $274.29 \mathrm{Db}$ & $245.43 \mathrm{Ec}$ & $302.22 \mathrm{Ea}$ \\
B100 & $310.37 \mathrm{Ba}$ & $276.10 \mathrm{Bc}$ & $306.17 \mathrm{Db}$ \\
\hline
\end{tabular}

Biodiesel mixture $-\mathrm{B} 0=0 \%, \mathrm{~B} 7=7 \%, \mathrm{~B} 10=10 \%, \mathrm{~B} 20=20 \%, \mathrm{~B} 30=30 \%$ and $\mathrm{B} 100=$ $100 \%$; Means followed by the same capital letter in the column and by the same lowercase letter in the row do not differ at $\mathrm{p} \leq 0.05$ by Tukey test 
(B0). At 1000 and $1600 \mathrm{rpm}$, the biodiesel mixtures have lower $\mathrm{NO}_{\mathrm{x}}$ emissions compared to the pure diesel. At $2400 \mathrm{rpm}$, the $\mathrm{NO}_{\mathrm{x}}$ emissions in pure diesel and biodiesel are equal, being lower in the mixtures. The $\mathrm{NO}_{x}$ emissions are lower for higher rotation speeds, differing significantly in all engine speed rotations (Table 3).

At $1000 \mathrm{rpm}$, the highest emissions are given by $\mathrm{B} 0$ and the lowest emissions come from B30 and B100. For the other rotation speeds, large variations and oscillations were observed, in line with the results of Ganjehkaviri et al. (2016).

According to Kumar et al. (2016b), it is possible to reduce $\mathrm{NO}_{\mathrm{x}}$ emissions from diesel cycle engines by using a combination of low-cetane-index biofuel mixtures and ignition delay. Kumar et al. (2016a) acknowledged that several studies show differences in biodiesel chemical composition, which is related to the origin source, leading to variations in performance and emission characteristics. Biodiesel obtained from saturated raw materials produce low $\mathrm{NO}_{\mathrm{x}}$ emissions and high resistance to oxidation.

One of the main reasons for the use of biodiesels lies in their ability to lower sulfur emissions $\left(\mathrm{SO}_{2}\right)$, which is one of the most dangerous pollutants emitted by fossil fuels. The data obtained in this study demonstrate that lower emissions are obtained with higher percentages of biodiesel added to the fuel.

For all rotation speeds, the lowest $\mathrm{SO}_{2}$ emissions were obtained for fuels with higher percentages of biodiesel, and $\mathrm{B} 30$ emitted the lowest $\mathrm{SO}_{2}$ concentrations of $65.78,52.47$ and $32.25 \mathrm{ppm}$ at 1000, 1600, and $2000 \mathrm{rpm}$, respectively (Table 4). Note that emissions of this gas decreased as the engine rotation speed increased.

The $\mathrm{SO}_{2}$ emissions were not determined in the case of pure biodiesel (B100), as this fuel is derived from vegetable oils, and therefore contains no sulfur. However, the analysis was applied to the other mixtures and the pure diesel, as diesel releases more $\mathrm{SO}_{2}$ than the biodiesel mixtures because of the lower sulfur content in vegetable-oil-based fuels (Rahim et al., 2016).

Table 3. Emissions of $\mathrm{NO}_{\mathrm{x}}$ (ppm) for different fuels and rotation speeds

\begin{tabular}{lccc}
\hline \multirow{3}{*}{ Fuel } & \multicolumn{3}{c}{ Rotation (rpm) } \\
\cline { 2 - 4 } & $\mathbf{1 0 0 0}$ & $\mathbf{1 6 0 0}$ & $\mathbf{2 4 0 0}$ \\
\hline B0 & $369.36 \mathrm{Aa}$ & $221.60 \mathrm{Ab}$ & $136.20 \mathrm{Ac}$ \\
B7 & $294.28 \mathrm{Da}$ & $203.87 \mathrm{Cb}$ & $125.02 \mathrm{Dc}$ \\
B10 & $320.52 \mathrm{Ba}$ & $203.90 \mathrm{Cb}$ & $128.94 \mathrm{Cc}$ \\
B20 & $315.42 \mathrm{Ca}$ & $213.46 \mathrm{Bb}$ & $133.96 \mathrm{Bc}$ \\
B30 & $279.35 \mathrm{Ea}$ & $204.78 \mathrm{Cb}$ & $129.23 \mathrm{Cc}$ \\
B100 & $259.26 \mathrm{Fa}$ & $204.49 \mathrm{Cb}$ & $136.60 \mathrm{Ac}$ \\
\hline
\end{tabular}

Biodiesel mixture - B0 $=0 \%, \mathrm{~B} 7=7 \%, \mathrm{~B} 10=10 \%, \mathrm{~B} 20=20 \%, \mathrm{~B} 30=30 \%$ and $\mathrm{B} 100=$ $100 \%$; Means followed by the same capital letter in the column and by the same lowercase letter in the row do not differ at $\mathrm{p} \leq 0.05$ by Tukey test

Table 4. Emissions of $\mathrm{SO}_{2}$ (ppm) for different fuels and rotation speeds

\begin{tabular}{cccc|}
\hline \multirow{2}{*}{ Fuel } & \multicolumn{3}{c|}{ Rotation (rpm) } \\
\cline { 2 - 4 } B0 & $\mathbf{1 0 0 0}$ & $\mathbf{1 6 0 0}$ & $\mathbf{2 4 0 0}$ \\
B7 & $77.84 \mathrm{Cc}$ & $65.09 \mathrm{Cb}$ & $45.61 \mathrm{Da}$ \\
B10 & $93.30 \mathrm{Dc}$ & $70.19 \mathrm{Db}$ & $44.51 \mathrm{Da}$ \\
B20 & $77.90 \mathrm{Cc}$ & $65.63 \mathrm{Cb}$ & $34.53 \mathrm{Ba}$ \\
B30 & $74.78 \mathrm{Bc}$ & $54.75 \mathrm{Bb}$ & $36.14 \mathrm{Ca}$ \\
\hline
\end{tabular}

Biodiesel mixture - $\mathrm{B} 0=0 \%, \mathrm{~B} 7=7 \%, \mathrm{~B} 10=10 \%, \mathrm{~B} 20=20 \%, \mathrm{~B} 30=30 \%$ and $\mathrm{B} 100=$ $100 \%$; Means followed by the same capital letter in the column and by the same lowercase letter in the row do not differ at $\mathrm{p} \leq 0.05$ by Tukey test
As reported by Miranda et al. (2013), sulfur emissions decreased for all mixtures, except for B7 at $1000 \mathrm{rpm}$ rotation. This reduction can be justified by the low or almost null amount of sulfur in biodiesel. Therefore, it is safe to say that the use of biodiesel significantly reduces sulfur emissions.

Carbon dioxide develops when there is a sufficient amount of oxygen present during the formation of $\mathrm{CO}$, as a product of combustion. $\mathrm{CO}_{2}$ emissions are the result of complete fuel combustion. According to Nalgundwar et al. (2016), $\mathrm{CO}_{2}$ emissions become insignificant in the atmosphere when absorbed mainly by plants, trees and plantations.

Observing the $\mathrm{CO}_{2}$ emissions for the various rotation speeds and fuels, the concentration of this gas is small in all situations, and the lowest emissions occur with the B10 mixture in the three speed rotation (Table 5).

Shahir et al. (2015) stated that oxygenated fuels emit a small amount of $\mathrm{CO}_{2}$ and water when burned, and that there are no great differences in their mixtures with diesel. These results corroborate those found in the present work. Pereira et al. (2007) found higher $\mathrm{CO}_{2}$ emissions in soybean biodiesel mixtures, suggesting more complete combustion.

The oxygen $\left(\mathrm{O}_{2}\right)$ behavior is important, as it may indicate the efficiency of the fuel burn. The data obtained in this study show that, for all fuels and rotation speeds, $\mathrm{O}_{2}$ emissions were below the atmospheric $21 \%$, indicating that the oxygen in the fuels was involved in the reaction and also reacted with a little of the oxygen injected into the cylinder, as shown in Table 6. The lower $\mathrm{O}_{2}$ emission was verified in the pure diesel (B0).

Perin et al. (2015) reported that $\mathrm{CO}_{2}$ emissions were different from $\mathrm{O}_{2}$ emissions. As the $\mathrm{CO}_{2}$ results from combustion, the bonding of atmospheric $\mathrm{O}_{2}$ to the carbon in the fuel means that the $\mathrm{CO}_{2}$ emission levels cannot be greater than the $21 \%$ of atmospheric $\mathrm{O}_{2}$. However, Das et al. (2018) proved that there are no major differences in performance (thermal efficiency, specific consumption and exhaust gas

Table 5. Emissions of $\mathrm{CO}_{2}$ (\%) for different fuels and rotation speeds

\begin{tabular}{|lccc|}
\hline \multirow{2}{*}{ Fuel } & \multicolumn{3}{c|}{ Rotation (rpm) } \\
\cline { 2 - 4 } & 1000 & 1600 & 2400 \\
B0 & $2.28 \mathrm{Ab}$ & $2.28 \mathrm{Ab}$ & $2.70 \mathrm{Ba}$ \\
B7 & $2.22 \mathrm{Bc}$ & $2.24 \mathrm{Bb}$ & $2.62 \mathrm{Da}$ \\
B10 & $1.99 \mathrm{Fc}$ & $2.13 \mathrm{~Eb}$ & $2.60 \mathrm{Ea}$ \\
B20 & $2.01 \mathrm{Ec}$ & $2.15 \mathrm{Db}$ & $2.63 \mathrm{Ca}$ \\
B30 & $2.21 \mathrm{Bc}$ & $2.23 \mathrm{Bb}$ & $2.70 \mathrm{Ba}$ \\
B100 & $2.05 \mathrm{Dc}$ & $2.22 \mathrm{Cb}$ & $2.72 \mathrm{Aa}$ \\
\hline
\end{tabular}

Biodiesel mixture - B0 $=0 \%, \mathrm{~B} 7=7 \%, \mathrm{~B} 10=10 \%, \mathrm{~B} 20=20 \%, \mathrm{~B} 30=30 \%$ and $\mathrm{B} 100=$ $100 \%$; Means followed by the same capital letter in the column and by the same lowercase letter in the row do not differ at $\mathrm{p} \leq 0.05$ by Tukey test

Table 6. Emissions of $\mathrm{O}_{2}$ (\%) for different fuels and rotation speeds

\begin{tabular}{lccc}
\hline \multirow{3}{*}{ Fuel } & \multicolumn{3}{c|}{ Rotation $(\mathbf{r p m})$} \\
\cline { 2 - 4 } B0 & $\mathbf{1 0 0 0}$ & $\mathbf{1 6 0 0}$ & $\mathbf{2 4 0 0}$ \\
B7 & $17.97 \mathrm{~Eb}$ & $17.98 \mathrm{Ea}$ & $17.40 \mathrm{Ec}$ \\
B10 & $18.12 \mathrm{Da}$ & $18.10 \mathrm{Db}$ & $17.57 \mathrm{Bc}$ \\
B20 & $18.43 \mathrm{Ba}$ & $18.23 \mathrm{Bb}$ & $17.59 \mathrm{Ac}$ \\
B30 & $18.45 \mathrm{Aa}$ & $18.26 \mathrm{Ab}$ & $17.60 \mathrm{Ac}$ \\
B100 & $18.15 \mathrm{Ca}$ & $18.14 \mathrm{Cb}$ & $17.47 \mathrm{Dc}$ \\
\hline
\end{tabular}

Biodiesel mixture $-\mathrm{B} 0=0 \%, \mathrm{~B} 7=7 \%, \mathrm{~B} 10=10 \%, \mathrm{~B} 20=20 \%, \mathrm{~B} 30=30 \%$ and $\mathrm{B} 100=$ $100 \%$; Means followed by the same capital letter in the column and by the same lowercase letter in the row do not differ at $\mathrm{p} \leq 0.05$ by Tukey test 
temperature) and engine emission characteristics (CO, HC and NO) when using diesel and biodiesel fuels.

Al-Iwayzy \& Yusaf (2017) analyzed the exhaust gases from engines powered by mixtures of biodiesel produced from microalgae and compared these emissions with pure diesel emissions. They concluded that there are significant statistical differences in $\mathrm{CO}, \mathrm{O}_{2}$ and $\mathrm{NO}_{x}$ exhaust emissions when compared to $\mathrm{B} 100$. Using $\mathrm{B} 100$, the engine showed a reduction of 28.0, 4.2 and $7.4 \%$ in $\mathrm{CO}, \mathrm{CO}_{2}$ and $\mathrm{NO}_{\mathrm{x}}$ emissions, respectively.

For biodiesel and its mixtures with diesel, variations are more noticeable when the engine is operating at low rotation speeds. This may indicate that biodiesels lead to poor engine efficiency; this may be because the motors are not calibrated to use $100 \%$ vegetable fuel.

\section{Conclusions}

1. The $\mathrm{CO}$ emissions when using $\mathrm{B} 0$ increased with the engine rotation speed. For the B30 and B100 mixtures, the lowest emissions occurred at $1600 \mathrm{rpm}$ and the highest emissions at $1000 \mathrm{rpm}$. The highest emissions occurred at the lowest rotation speed, whereas for B0 and B7, the highest emissions occurred at the highest rotation speed.

2. The lowest $\mathrm{SO}_{2}$ emissions were obtained with fuels containing higher biodiesel percentages and operating at higher rotation speeds.

3. Nitrous oxides and carbon dioxide emissions decrease with higher engine rotation speed.

4. Overall, higher percentages of biodiesel in the fuel mixture result in a less polluting fuel.

\section{Literature Cited}

Al-Iwayzy, S. H.; Yusaf, T. Diesel engine performance and exhaust gas emissions using Microalgae Chlorella protothecoides biodiesel. Renewable Energy, v.101, p.690-701, 2017. https://doi. org/10.1016/j.renene.2016.09.035

ANP - Agência Nacional do Petróleo, Gás e Biocombustível. Resolução $\mathrm{n}^{\circ} 45$, de 26 de agosto de 2014. Brasília: Diário Oficial da União, 2014. 13p.

ANP - Agência Nacional do Petróleo, Gás e Biocombustível. Resolução no 30, de 24 de junho de 2016. Brasília: Diário Oficial da União, 2016a. 7p.

ANP - Agência Nacional do Petróleo, Gás e Biocombustível. Resolução nº 46, de 01 de nov. 2016. Brasília: Diário Oficial da União, 2016b. 32p.

Can, Ö.; Öztürk, E.; Yücesu, H. S. Combustion and exhaust emissions of canola biodiesel blends in a single cylinder DI diesel engine. Renewable Energy, v.109, p.73-82, 2017. https://doi.org/10.1016/j. renene.2017.03.017

Das, M.; Sakar, M.; Datta, A.; Santra, A. K. An experimental study on the combustion, performance and emission characteristics of a diesel engine fuelled with diesel-castor oil biodiesel blends. Renewable Energy, v.119, p.174-184, 2018. https://doi. org/10.1016/j.renene.2017.12.014

Ferreira, D. F. Sisvar: A guide for its bootstrap procedures in multiple comparisons. Ciência e Agrotecnologia, v.38, p.109-112, 2014. http://dx.doi.org/10.1590/S1413-70542014000200001
Ganjehkaviri, A.; Jaafar, M. N. M.; Hosseini, S. E.; Musthafa, A. B. Performance evaluation of palm oil-based biodiesel combustion in an oil burner. Energies, v.9, p.1-10, 2016. https://doi.org/10.3390/ en9020097

Gharehghani, A.; Mirsalim, M.; Hosseini, R. Effects of waste fish oil biodiesel on diesel engine combustion characteristics and emission. Renewable Energy, v.101, p.930-936, 2017. https://doi. org/10.1016/j.renene.2016.09.045

Hasan, M. M.; Rahman, M. M. Performance and emission characteristics of biodiesel-diesel blend and environmental and economic impacts of biodiesel production: A review. Renewable and Sustainable Energy Reviews, v.74, p.938-948, 2017. https:// doi.org/10.1016/j.rser.2017.03.045

Islam, S.; Ahmed, A. S.; Islam, A.; Aziz, S. A.; Xian, L. C.; Mridha, M. Study on emission and performance of diesel engine using castor biodiesel. Journal of Chemistry, v.2014, p.1-8, 2014. http://dx.doi. org $/ 10.1155 / 2014 / 451526$

Kumar, A.; Shukla, S. K.; Tierkey, J. V. A Review of research and policy on using different biodiesel oils as fuel for C.I. engine. Energy Procedia, v.90, p.292-304, 2016a. https://doi.org/10.1016/j. egypro.2016.11.197.

Kumar, B. R.; Saravanan, S.; Rana, D.; Nagendran, A. Use of some advanced biofuels for overcoming smoke/ $\mathrm{NO}_{\mathrm{x}}$ trade-off in a lightduty DI diesel engine. Renewable Energy, v.96, p.687-699, $2016 \mathrm{~b}$. https://doi.org/10.1016/j.renene.2016.05.029

Kumar, K.; Sharma, M. P. Performance and emission characteristics of a diesel engine fuelled with biodiesel blends. International Journal of Renewable Energy Research, v.6, p.658-662, 2016.

Lahane, S.; Subramanian, K. A. Effect of different percentages of biodiesel-diesel blends on injection, spray, combustion, performance, and emission characteristics of a diesel engine. Fuel, v.139, p.537-545, 2015. https://doi.org/10.1016/j.fuel.2014.09.036

Miranda, G. R. de; Lisboa, H. de M.; Meier, H. F.; Vieira, M. M.; Hartmann, E. M. Avaliação das emissões de CO, NO, $\mathrm{NO}_{\mathrm{x}}$, e $\mathrm{SO}_{2}$ provenientes da combustão, em motor monocilíndrico, de misturas de diesel e biodiesel de óleo de fritura. Revista Ciências Ambientais, v.7, p.33-43, 2013. http://dx.doi.org/10.18316/1180

Nalgundwar, A.; Paul, B.; Sharma, S. K. Comparison of performance and emissions characteristics of DI CI engine fueled with dual biodiesel blends of palm and jatropha. Fuel, v.173, p.172-179, 2016. https://doi.org/10.1016/j.fuel.2016.01.022

Öztürk, E. Performance, emissions, combustion and injection characteristics of a diesel engine fuelled with canola oil-hazelnut soapstock biodiesel mixture. Fuel Processing Technology, v.129, p.183-191, 2015. https://doi.org/10.1016/j.fuproc.2014.09.016

Peng, D.-X. Exhaust emission characteristics of various types of biofuels. Advances in Mechanical Engineering, v.7, p.1-7, 2015. https://doi.org/10.1177/1687814015593036

Pereira, R. G.; Oliveira, C. D.; Oliveira, J. L.; Oliveira, P. C. P.; Fellows, C. E.; Piamba, O. E. Exhaust emissions and electric energy generation in a stationary engine using blends of diesel and soybean biodiesel. Renewable Energy, v.32, p.2453-2460, 2007. https://doi.org/10.1016/j.renene.2006.05.007

Perin, G. F.; Schlosser, J. F.; Farias, M. S. de; Estrada, J. S.; Treichel, H.; Galon, L. Emissões de motor agrícola com o uso de diferentes tipos de diesel e concentrações de biodiesel na mistura combustível. Pesquisa Agropecuaria Brasileira, v.50, p.1168-1176, 2015. http:// doi.org/ 10.1590/S0100-204X2015001200006 
Rahim, N. A.; Jaafar, M. N. M.; Sapee, S.; Elraheem, H. F. Effect on particulate and gas emissions by combusting biodiesel blend fuels made from different plant oil feedstocks in a liquid fuel burner. Energies, v.9, p.1-18, 2016. http://doi.org/10.3390/ en9080659

Reis, E. F. dos; Cunha, J. P. B.; Mateus, D. L. S.; Delmond, J. G.; Couto, R. F. Desempenho e emissoes de um motor-gerador ciclo diesel sob diferentes concentrações de biodiesel de soja. Revista Brasileira de Engenharia Agricola e Ambiental, v.17, p.565-571, 2013. http://dx.doi.org/10.1590/S141543662013000500015
Shahir, S. A.; Masjuki, H. H.; Kalam, M. A.; Imran, A.; Ashraful, A. M. Performance and emission assessment of diesel-biodiesel-ethanol/ bioethanol blend as a fuel in diesel engines: A review. Renewable and Sustainable Energy Reviews, v.48, p.62-78, 2015. https://doi. org/10.1016/j.rser.2015.03.049

Tomasevic, A. V.; Siler-Marinkovic, S. S. Methanolysis of used frying oils. Fuel Processing Technology, v.81, p.1-6, 2003. https://doi. org/10.1016/S0378-3820(02)00096-6

Vichi, F. M.; Mansor, M. T. C. Energia, meio ambiente e economia: O Brasil no contexto mundial. Química Nova, v.32, p.757-767, 2009. https://doi.org/10.1590/S0100-40422009000300019 